\title{
Cuvier and Medicine
}

\author{
By Erwin H. Ackerknecht $\dagger$
}

Georges Cuvier (1769-1832), this great and incredibly gifted scientific creator (e.g. in paleontology and comparative anatomy) and organiser, is undoubtedly one of the most eminent scientists of the 19th century. He is an exception; he is one of the few scientists of his period who had not first received medical training (whatever Dr. Véron says). There have been medics, outstanding as scientists, from Empedokles, Theophrastus, Erasistratus over Avicenna, Agricola, Paracelsus, Copernicus, Cardanus, Descartes, Linné, Daubenton, Fourcroy, Berthollet down to Th. Young, R. Mayer and Helmholtz. Cuvier's Museum was one of the few pure research institutions of his country. Due to his qualities he rose in spite of remaining faithful to the ostracised protestant creed of his forefathers ${ }^{1}$.

It was almost unavoidable that Cuvier should have interesting contacts with medicine though they have so far not yet found much attention.

As the secretary of the "Institut" (Academy), one of his many jobs, Cuvier wrote since 1800 the annual reports on the works submitted to the institution and the obituaries of the deceased members. In both categories were numerous medical works and researchers present. As to the medical items in the first category, Cuvier reported e.g. alone for 1818 intelligently on such important medical work as that of Portal (embryology), Percy (méricisme), Laennec (his "cylinder"), Darcet (gilder's disease), Contré (cupping - it is interesting that the French, then internationally the medical leader, did already less cupping than their neighbours. In exchange I was cupped still for pneumonia as a French soldier in 1941!), Richeraud (pleurectomy), Roux (cataract extraction).

In his function as secretary Cuvier wrote no less than 39 necrologies between 1800 and 1832 among them of such medical luminaries as Darcet, de Saussure, Desessarts, Pallas, Hallé, Corvisart, Pinel, Tenon.

In 1808 Napoleon charged Cuvier to write a "Rapport Historique sur les progrès des Sciences Naturelles depuis 1789 et sur leur Etat actuel". This report is subdivided in chapters on chemistry, natural history, medicine and agriculture. The chapter on medicine is not only of interest in showing how the leading French scientist of the period saw the medicine of his time, but it reveals also an amazing amount of knowledge and judgement in a "layman". 
He praises, by the way, the doctors of the past "without whom probably no natural sciences would exist".

He is opposed to the fashionable "Brownism", and German "Naturphilosophie". This is not surprising in view of his opposition to speculative theories (in spite of his education in Stuttgart). He feels more mildly about nosologies. But he prefers studies on individual diseases like plague and leprosy (during the Egyptian campaign) or the studies on tuberculosis and rickets by Portal.

He praises the medical theses written now in Paris. And among the 10 students he mentions by name, there are indeed no less than 5 who became eminent. He regards as the most important orientation the search for the lesion (Pinel, Bichat) and praises the new work in pathological anatomy by Portal, Corvisart and the young researchers Dupuytren, Bayle and Laennec.

Pinel's psychiatry, especially his therapeutics, seems to him a great step forward. He is quite enthusiastic about French work in elaborating the Jennerian invention of vaccination. He is positif as to new desinfecient substances. He recommends a few new medicaments like belladonna and digitalis, where he promptly recommends their use in the contemporary way, that is the wrong place ${ }^{2}$. He is rather sceptical (and rightly so) when giving a list of then fashionable medicaments and positively salutes the abolition of old useless composed remedies. He refers to the work of Alibert, Barbier etc. in Materia medica.

Surgery has profited from war experiences (Larrey, Percy). It holds her old international position and has found numerous new techniques in tracheotomy, aneurysma and eye diseases.

A very great progress he sees in the new medical education, which has introduced now clinical education everywhere in France. He greets the development of legal medicine and public health (Fodéré, Hallé, Desessarts) as well as the improvement in personal hygiene (food, dress, housing) during the past 30 years! This report comes so close to our present day view of the period that it probably could be printed in a medical history text without many additions or deletions.

This piece of history of science, done on order, made Cuvier cultivate the field up to the very end. His last unfinished course in the Collège de France in 1832 was on "Histoire des sciènces naturelles depuis leur origine jusqu'à nos jours chez tous les peuples connus" (published 1841-45 in 5 volumes by Mad. de Saint Agty). It covered the whole history of science from the beginning to the end of the 18th century. In this book, medicine has not a separate chapter 
like in the 1808 report. Subdivisions are made since the 16th century, but they exist only for anatomy, zoology, botany, mineralogy, chemistry. What there is reported on medicine, is incorporated in anatomy and zoology. Of particular interest are the chapters on Bichat, Galvanism and scientific voyages in Volume V.

Cuvier had an eye also for concrete medical problems. When on a mission to Holland in 1811 he was consulted on account of the low scholastic accomplishments of the Dutch boys. He found the solution: malnutrition ${ }^{3}$.

Though opposed to speculative theories in science Cuvier dealt in his reception speech in the Academy in 1818 mainly with three stages in the development of human knowledge: the inspirational (Homer to Milton), the stage of reflexion (Anaxagoras to Pascal) and the descriptive (Buffon and thereafter). For anybody, who has read Aug. Comte's "Philosophie positive" (Nachdruck Berlin 1975) the parallel with Comte's three stages: the theological-fictif, the metaphysical-abstract, the descriptif-positif is surprising. The resemblance of the two schemes is too great as to see here a mere accident. But it is after all not unnatural, that Comte should more or less repeat in 1822 what the leading French scientist had claimed in 1818. And it was never one of A. Comte's habits, to give all his sources.

The two doctors who took care of Cuvier in his last mysterious disease (Cholera?) were wellchosen. They were the best available in the Paris of 1832: Dupuytren and Andral.

Cuvier's last relation to medicine was postmortal. The autopsy revealed a very unusual circumference of the skull: $60,5 \mathrm{~cm}$ and an even more unusual brain of 1,823 gramm, which gave rise to many medical discussions.

\section{Footnotes}

1 M. Lee, Mémoires du Baron Cuvier. Paris 1833

2 Rapport p. 351, E. H. Ackerknecht, Bull. Hist. Med. 36: 425, 1962

3 Mémoires, p. 33 